\title{
Homeotic transformations and number changes in the vertebral column of Triturus newts
}

Maja Slijepčević, Frietson F Galis, Jan W Arntzen, Ana Ivanović

We explored intraspecific variation in vertebral formulae, more specifically the variation in the number of thoracic vertebrae and frequencies of transitional sacral vertebrae in Triturus newts (Caudata: Salamandridae). Within salamandrid salamanders this monophyletic group shows the highest disparity in the number of thoracic vertebrae and considerable intraspecific variation in the number of thoracic vertebrae. Triturus species also differ in their ecological preferences, from predominantly terrestrial to largely aquatic. Following Geoffroy St. Hilaire's and Darwin's rule which states that structures with a large number of serially homologous repetitive elements are more variable than structures with smaller numbers, we hypothesized that the variation in vertebral formulae increases in more elongated species with a larger number of thoracic vertebrae. We furthermore hypothesized that the frequency of transitional vertebrae will be correlated with the variation in the number of thoracic vertebrae within the species. We also investigated potential effects of species hybridization on the vertebral formula. The proportion of individuals with a number of thoracic vertebrae different from the modal number and the range of variation in number of vertebrae significantly increased in species with a larger number of thoracic vertebrae. Contrary to our expectation, the frequencies of transitional vertebrae were not correlated with frequencies of change in the complete vertebrae number. The frequency of transitional sacral vertebra in hybrids did not significantly differ from that of the parental species. Such a pattern could be a result of selection pressure against transitional vertebrae and/or a bias towards the development of full vertebrae numbers. Although our data indicate relaxed selection for vertebral count changes in more elongated, aquatic species, more data on different selective pressures in species with different numbers of vertebrae in the two contrasting, terrestrial and aquatic environments are needed to test for causality. 
1 Homeotic transformations and number changes in the vertebral column of

\section{Triturus newts}

\author{
Maja D. Slijepčević ${ }^{1}$, Frietson Galis², Jan W. Arntzen² and Ana Ivanović ${ }^{2,3}$
}

${ }^{1}$ Institute for Biological Research "Siniša Stanković", University of Belgrade, Serbia

${ }^{2}$ Naturalis Biodiversity Center, Leiden, The Netherlands

${ }^{3}$ Institute of Zoology, Faculty of Biology, University of Belgrade, Serbia

Corresponding author

Ana Ivanović,

ana@bio.bg.ac.rs

Abstract

We explored intraspecific variation in vertebral formulae, more specifically the variation in the number of thoracic vertebrae and frequencies of transitional sacral vertebrae in Triturus newts (Caudata: Salamandridae). Within salamandrid salamanders this monophyletic group shows the highest disparity in the number of thoracic vertebrae and considerable intraspecific variation in the number of thoracic vertebrae. Triturus species also differ in their ecological preferences, from predominantly terrestrial to largely aquatic. Following Geoffroy St. Hilaire's and Darwin's rule which states that structures with a large number of serially homologous repetitive elements are more variable than structures with smaller numbers, we hypothesized that the variation in vertebral formulae increases in more elongated species with a larger number of thoracic vertebrae. We furthermore hypothesized that the frequency of transitional vertebrae will be correlated with the variation in the number of thoracic vertebrae within the species. We also investigated potential effects of species hybridization on the vertebral formula. The proportion of individuals with a number of thoracic vertebrae different from the modal number and the range of variation in number of vertebrae significantly increased in species with a larger number of thoracic vertebrae. Contrary to our expectation, the frequencies of transitional vertebrae were not correlated with frequencies of change in the complete vertebrae number. The frequency of transitional sacral vertebra in hybrids did not significantly differ from that of the parental species. Such a pattern could be a result of selection pressure against transitional vertebrae and/or a bias towards the development of full vertebrae numbers. Although our data indicate 
relaxed selection for vertebral count changes in more elongated, aquatic species, more data on different selective pressures in species with different numbers of vertebrae in the two contrasting, terrestrial and aquatic environments are needed to test for causality.

\section{Introduction}

The vertebral column consists of repetitive, serially homologous skeletal elements - vertebrae. Along the anterior-posterior axis, vertebrae are classified into regions, with a conserved order and specific sizes and shapes (e.g. Starck, 1979). The strong regionalization of the vertebral column is already present early in the evolution of tetrapods (Ahlberg, Clack \& Blom, 2005). In the early tetrapod Ichthyostega, five regions (cervical, thoracic, lumbar, sacral and caudal) can be recognized as in many extant amniotes.

Vertebrae develop from embryonic segments (somites) that are generated from the presomitic mesoderm in a sequential head-to tail order. This process involves a molecular oscillator, the segmentation clock, that regulates the periodicity of segment formation (Cooke \& Zeeman, 1976; Palmeirim et al., 1997; Dequéant \& Pourquié, 2008; Gomez \& Pourquié, 2009). The duration of segment formation (somitogenesis) and the speed of the segmentation clock determine the total number of segments formed, and hence, the total number of vertebrae (Gomez et al., 2008, 2009). The determination of the identity of the vertebrae (e.g. cervical or thoracic) occurs as part of the early head-to-tail patterning of the presomitic mesoderm and early somites. This head-totail patterning involves complex genetic mechanisms that include various signaling molecules, with an essential mediating role for the well-known Hox genes (e.g. Dubrulle, McGrew \& Pourquié, 2001; Diezdel-Corral et al., 2003; Aulehla \& Pourquié, 2010; Mallo, Wellik \& Deschamps, 2010; Woltering, 2012; Wong et al., 2015). It is thought that the segmentation process and the head-to-tail patterning of the segments by the Hox genes can be dissociated and that this dissociation has allowed for the spectacular evolutionary diversification of vertebral formulae (Carapuço et al., 2005; Gomez \& Pourquié, 2009; Schroeter et al., 2010; Harima et al.,2013; Wong et al., 2015). When there are shifts of vertebral boundaries, e.g. the cervicothoracic boundary, these shifts involve changes in the Hox patterning of the somites along the head-to-tail axis. If indeed the segmentation process and the head-to-tail patterning of the segments are dissociated, the shifts of vertebral boundaries necessarily involve homeotic transformations of vertebrae. The involvement of homeotic transformations is further supported 
by the observation that in humans, xenarthra and afrotherians, intraspecific changes of the cervico-thoracic or thoraco-lumbar boundary almost always involve transitional vertebrae, i.e. partial homeotic transformations, also when the number of presacral or total vertebrae is changed (Galis et al., 2006; Varela-Lasheras et al., 2011; Ten Broek et al., 2012). This also confirms that initial mutations for homeotic transformations usually lead to incomplete homeotic transformations, resulting in transitional vertebral identities.

In mammals, changes in the number of cervical vertebrae are associated with deleterious pleiotropic effects that lead to selection against such homeotic transformations (Galis \& Metz, 2003; Varela-Lasheras et al., 2011). In two mammalian groups (sloths and manatees) with low activity and metabolic rates, the exceptional numbers of cervical vertebrae most likely resulted from the effective breaking of pleiotropic constraints due to a relaxation of stabilizing selection against the pleiotropic effects (known as congenital abnormalities, Varela-Lasheras et al., 2011). Furthermore, Galis et al. (2014) concluded that biomechanical problems associated with initial homeotic transformations (transitional vertebrae) in fast running mammals result in strong selection against changes of the presacral vertebral counts in these species.

In other tetrapods the number of vertebrae in different regions can be more variable. Well-known examples are the variable number of cervical vertebrae in birds (Woolfenden, 1961) and the variable number of presacral vertebrae in squamates (Carroll, 1997; Müller et al., 2010). In both cases, these regions have a large number of vertebrae. Geoffroy St. Hilaire has postulated that as a rule - structures with a large number of serially homologous repetitive elements are more variable than structures with smaller numbers (Geoffroy St. Hilaire, 1932). This notion was supported by Darwin (Darwin, 1860). Along the same line, Bateson (1894) concluded that series containing large numbers of undifferentiated parts are more variable than series made up of a few, more differentiated parts.

In tailed amphibians, the presacral vertebrae vary in their number but only little in shape. A single, sacral vertebra is morphologically very similar to the vertebrae from the thoracic or trunk region, with more robust processes for attachment of the sacral ribs which are also thicker than regular thoracic ribs. There is considerable intraspecific variation in the number of thoracic vertebrae in many species of salamanders (Adolphi, 1898; Gerecht, 1929; Peabody \& Brodie, 1975; Jockusch, 1997; Litvinchuk \& Borkin, 2003). Intraspecific variation originally results from homeotic transformations that are subsequently maintained in the population. In salamanders, 
96

transitional vertebrae at the thoraco-sacral boundary have been frequently reported (Adolphi, 1898; Gerecht, 1929; Highton, 1960; Worthington, 1971; Jockush, 1997; Arntzen et al., 2015). Such transitional vertebrae with partial thoracic and partial sacral identity result from incomplete homeotic transformations. Therefore, the frequencies of transitional vertebrae could be related to the amount of variation in the number of thoracic vertebrae within species. Data on changes in axial pattering and homeotic transformations in amphibians are relatively scarce and more data are necessary for understanding the evolution of axial pattering in amphibians and the tetrapods. In this study we explore the relationship between variation in the number of thoracic vertebrae and transitional sacral vertebrae using eight species of the monophyletic genus Triturus newts as a model system. Within the family Salamandridae, which is the second most diverse group of tailed amphibians, Triturus newts are the most disparate in the number of thoracic vertebrae (Arntzen et al., 2015). Triturus species form a morphocline from the predominantly terrestrial $T$. marmoratus and T. pygmaeus with a short and stout body and 12 thoracic vertebrae to the slender and elongated, largely aquatic $T$. cristatus and $T$. dobrogicus with 15-17 thoracic vertebrae (Arntzen, 2003). Triturus species also display considerable intraspecific variation in vertebral numbers (Gerecht, 1929; Crnobrnja et al., 1997; Arntzen et al., 2015). Moreover, there is a well-documented, extensive hybridization in the area of sympatry of T. marmoratus (12 thoracic vertebrae) and T. cristatus (15 thoracic vertebrae). The hybridization of these two species leads to sterile F1 hybrids with intermediate morphologies and number of thoracic vertebrae (Vallée, 1959; Arntzen et al., 2009). Interspecific hybridization at contact zones also occurs between other Triturus species with parapatric distributions (Mikulíček et al., 2012; Arntzen, Wielstra \& Wallis, 2014), providing the opportunity to investigate the relationship between vertebral number and frequencies of transitional sacral vertebrae. Here, we compared variation in the number of thoracic vertebrae and transitional sacral vertebrae among Triturus species, T. marmoratus $\times$ T. cristatus $\mathrm{F} 1$ hybrids with parental species, and populations from contact zones with populations away from contact zones. More specifically, we explored the intra- and interspecific variation in number of the thoracic vertebrae and frequencies of transitional vertebrae at the thoraco-sacral boundary to test the following hypotheses: 1. Species with more vertebrae in the thoracic region are more variable in the number of thoracic vertebrae than those with fewer vertebrae in the thoracic region. 
126 2. The higher the variation in the number of thoracic vertebrae, the higher the frequencies of

127 transitional vertebrae are. In hybrids, we would expect that the range of variation in the number

128 of vertebrae overlaps the ranges of parental species' variation. Also, we would expect the higher

129 frequencies of transitional vertebrae in comparison with parental species. In species with

130 parapatric distributions we would expect the higher variation in the number of vertebrae and the

131 higher frequencies of transitional vertebrae in populations from contact zones in comparison with

132 populations away from contact zones.

134 Materials and Methods

135 Triturus newts and their characteristics

136 The vertebral column in Triturus newts is differentiated in: the cervical region-consisting of a

137 single anterior vertebra, the atlas; the thoracic (trunk) region,--consisting of a rib-bearing

138 vertebrae; the sacral region - usually a single vertebra with well-developed stout transverse

139 processes for the attachment of sacral ribs and pelvic girdle; the caudosacral region - up to three

140 vertebrae that continue from the caudal to the sacral vertebra and are associated with the pelvic

141 musculature and cloaca and the caudal region - the remaining vertebrae in the tail (Fig. 1). The

142 body elongation in Triturus species appears to be correlated with the length of the aquatic phase

143 - more terrestrial species have a short and stout trunk with relatively longer legs compared to

144 species with a more aquatic life style which have a more elongated trunk and relatively shorter

145 legs. Body elongation involves a larger number of thoracic vertebrae. More specifically, the

146 number of thoracic vertebrae in the vertebral formulae varies from 12 in T. marmoratus and T.

147 pygmaeus, which have a short aquatic phase (T. marmoratus only two months), 13 in $T$. karelinii

148 and T. ivanbureschi, 14 in T. macedonicus and T. carnifex, 15 in T. cristatus to 16 or 17 in $T$.

149 dobrogicus, the most aquatic species which has six months long aquatic phase (Arntzen, 2003)

150 (Fig. 2).

151 The distribution of the genus Triturus is well documented (Arntzen, Wielstra \& Wallis, 2014).

152 Triturus cristatus and T. marmoratus have an area of range overlap in France and can often be

153 found in syntopy (Arntzen \& Wallis, 1991; Lescure \& de Massary, 2012). Other Triturus species

154 contact zones are generally narrow and show a weak but significant negative relationship

155 between the level of hybridization and the genetic distance of species pairs (Arntzen, Wielstra \&

156 Wallis, 2014). 
Material analysed

159

We analysed axial skeletons of 1436 adult newts that originate from 126 populations of all eight species of Triturus newts (Fig. 3). For this study we used X-ray images of good quality and cleared and stained skeletons. The X-ray images were obtained on a Faxitron $43855 \mathrm{C} / \mathrm{D}$ with an exposure of 20-40s at $3 \mathrm{~mA}$ and $70 \mathrm{kV}$. Other material was cleared with trypsin and $\mathrm{KOH}$ and stained with Alizarin Red S for bone deposition (Dingerkus \& Uhler, 1977) and stored in glycerine. Analyzed specimens are from the batrachological collection of the Institute for Biological Research "Siniša Stanković”, Belgrade, Serbia $(\mathrm{N}=601)$ and from the collection of the Naturalis Biodiversity Center, Leiden, The Netherlands $(\mathrm{N}=835)$. Our material covers the geographic, taxonomic and molecular genetic diversity of the genus. On the basis of well documented species distributions (Mikulíček et al., 2012; Arntzen, Wielstra \& Wallis, 2014) populations were assigned as "central" or "fringe" based upon their geographical position away $(>=50 \mathrm{~km})$ or close to $(<50 \mathrm{~km})$ congeneric species. For localities and sample size per

Scoring vertebral formulae and transitional thoraco-sacral vertebrae

We determined the vertebral formula by counting the number of cervical (C), thoracic (T) and sacral vertebrae (S). The caudosacral and caudal regions are excluded from our formula as the detailed inspection of cleared and stained specimens showed that a variable number of caudosacral vertebrae frequently bear small, much reduced ribs which could be fused with transverse processes and cannot always be distinguished on X-ray images. The number of tail vertebrae was available only for a subset of specimens; in most specimens tails had been removed for enzyme electrophoretic analyses or were broken or damaged. Homeotic transformations of thoracic vertebra into sacral vertebra, or vice versa (transitional sacral vertebra having half of the identity of thoracic vertebra and half of the identity of sacral vertebra) were assigned 0.5 and this score was added to the number of complete thoracic vertebrae. Only complete changes of identity on one side of the vertebrae (on one side thoracic and on one side sacral) were declared transitional. Right side asymmetry of a sacral vertebra is scored when the thoracic rib is present on the right side and the sacral rib on the left side of transitional thoraco-sacral vertebra and vice versa for left side asymmetry For a 3D model of 
188 regular and transitional thoraco-sacral vertebra obtained by CT-scanning see Supplementary data. We assumed that the frequency of transitional vertebrae with a complete change of identity at one side of vertebra reflects the frequency of all homeotic transformations, including more gradual ones, which could not always be scored.

\section{Statistical analyses}

The Spearman correlation coefficient $\left(r_{\mathrm{s}}\right)$ was used to quantify correlation between species modal numbers of thoracic vertebrae $\left(T_{n}\right)$ and 1$)$ the percentage of individuals with the number of complete thoracic vertebrae different from the modal number $\left(\mathrm{T}_{\mathrm{var}}\right)$ and 2$)$ the range of variation in the number of thoracic vertebrae $\left(T_{\text {range }}\right)$ within species. The same measure was used to quantify the relationship between percentages of transitional sacral vertebrae $\left(\mathrm{S}_{\mathrm{tr}}\right)$ and $\mathrm{T}_{\mathrm{var}}$ and $\mathrm{T}_{\text {range. }}$ To test for differences between hybrids and parental species across fringe and central populations we used the G-test of independence. To analyse interspecific variation in a phylogenetic context, we used a well resolved time-calibrated phylogeny of genus Triturus (Arntzen et al., 2015) shown in Figure 2. Associations derived from common ancestry were evaluated by calculating the strength of the phylogenetic signal for analysed variables $\left(T_{n}, T_{v a r}\right.$, $\mathrm{T}_{\text {range }}$ and $\mathrm{S}_{\mathrm{tr}}$ ). The procedure involves the random permutation of the variables over the terminal units of the phylogenetic tree (10,000 iterations), in which the test statistic is the total amount of squared change summed over all branches of the tree. We applied the phylogenetic independent contrasts approach (Felsenstein, 1985) to obtain a set of independent contrasts. The regression of 1) $T_{v a r}$ independent contrasts on $T_{n}$ independent contrasts and 2) $T_{\text {range }}$ independent contrasts on $\mathrm{T}_{\mathrm{n}}$ independent contrasts were used to explore the relationship between evolutionary change in the number of the thoracic vertebra in vertebral formula and amount of variation in the number of thoracic vertebrae. The regressions of $\mathrm{T}_{\mathrm{var}}$ and $\mathrm{T}_{\text {range }}$ independent contrasts on $\mathrm{S}_{\mathrm{tr}}$ were used to explore changes and frequencies of transitional vertebrae, taking the similarity due to shared ancestry into account.

\section{Results}

\section{Vertebral formula and transitional sacral vertebra in Triturus newts}

The most common vertebral formulae were 1C 12T 1S in T. marmoratus and T. pygmaeus, 1C 13T 1S in T. karelinii and T. ivanbureschi, 1C 14T 1S in T. macedonicus and T. carnifex, 1C 15T 
219 1S in T. cristatus and 1C 17T 1S in T. dobrogicus (See Fig. 2 and Table 1). The percentage of 220 individuals with a number of complete thoracic vertebrae different from the modal number $\left(\mathrm{T}_{\mathrm{var}}\right)$ 221 varied among species, from $3.6 \%$ in $T$. pygmaeus to $24.6 \%$ in $T$. dobrogicus. The range of 222 variation in the number of thoracic vertebrae is $12-13$ observed in T. marmoratus and T.

223 pygmaeus, 12 - 14 in T. ivanbureschi, 12 - 14 in T. karelinii, 13 - 15 in T. macedonicus, 13 - 16 224 in T. carnifex, 13 - 16 in T. cristatus and 15-18 in T. dobrogicus (see Table 1). The variation in 225 the vertebrae number per population is shown in Supplementary Table S2.

226 Frequencies of recorded homeotic transformations in Triturus newt species are listed in Table 2.

227 The least common is the homeotic transformation of cervical vertebra with the thoracic rib

228

229

230

231

232

233

234

235

236

237

238

239

240

241

242

243

244

245

246

247

248

249 attached to one or both sides of the vertebra, recorded six times $(0.41 \%)$ and in four out of eight species. Two types of transitional vertebrae at the thoraco-sacral boundary were recorded. The first type involves changes of two succeeding vertebrae - transitional sacral vertebra with thoracic rib at one side and sacral rib at the other side, followed by transitional vertebra having sacral rib at one side (opposite than previous vertebra) and no rib attached on the other side (see Figs 1 and 4). The second type of transitional sacral vertebra involves transitional thoraco-sacral vertebra, with a thoracic rib at one side and a sacral rib at the other, followed by regular sacral vertebra. The transitional changes involving two adjacent vertebrae, thoracic and sacral (here termed transitional sacral) are more frequent than transitional changes of thoracic to sacral vertebra without changes of sacral vertebra. Excluding F1 hybrids, we recorded a transitional sacrum in 70 out of 1368 specimens (5.1\%). Both, right side and left side asymmetries were recorded (Table 2). We found that $\mathrm{T}_{\mathrm{n}}$ and $\mathrm{T}_{\mathrm{var}}$ are significantly positively correlated $\left(\mathrm{r}_{\mathrm{s}}=0.75, p\right.$ $=0.023$ ), indicating that species with more vertebrae in the thoracic region are more variable in the number of vertebrae. A significant correlation was also found between $T_{n}$ and $T_{\text {range }}\left(r_{s}=\right.$ $0.90, p=0.002$ ), indicating that the range of variation was significantly higher in species with more thoracic vertebrae. We did not find a correlation between $\mathrm{S}_{\mathrm{tr}}$ and $\mathrm{T}_{\mathrm{var}}\left(\mathrm{r}_{\mathrm{s}}=0.31, p=0.46\right)$ or between $\mathrm{S}_{\text {tr }}$ and $\mathrm{T}_{\text {range }}\left(\mathrm{r}_{\mathrm{s}}=0.13, p=0.76\right)$.

\section{Phylogenetic comparative analyses}

We found a statistically significant phylogenetic signal in $\mathrm{T}_{\mathrm{n}}(p=0.013)$ and $\mathrm{T}_{\text {range }}(p=0.033)$ and no significant phylogenetic signal in $\mathrm{T}_{\mathrm{var}}(p=0.730)$ and $\mathrm{S}_{\mathrm{tr}}(p=0.970)$. The regression of 1$)$ $\mathrm{T}_{\mathrm{var}}$ independent contrasts on $\mathrm{T}_{\mathrm{n}}$ independent contrasts $(p=0.018)$ and 2$)$ the regression of $\mathrm{T}_{\text {range }}$ 
250 independent contrasts on $\mathrm{T}_{\mathrm{n}}$ independent contrasts revealed a significant relationship between the

251 increase in the number of thoracic vertebrae and the amount of variation in the number of

252 vertebrae $(p=0.006)$. We found no significant relationship between $\mathrm{T}_{\text {range }}$ independent contrasts

253 and $\mathrm{S}_{\text {tr }}$ independent contrasts $(p=0.413)$.

254

255

Hybridization and variation in vertebral formula

256

There were statistically significant differences in changes in vertebral formulae between central' and fringe populations (G-test for independence, $\mathrm{G}=18.61, p=0.001$ ). For fringe populations, the observed range of variation in number of thoracic vertebrae is 12-15 in T. ivanbureschi, 1316 in T. macedonicus, 13-15 in T. carnifex, 13-17 in T. cristatus and 14-18 in T. dobrogicus. In T. dobrogicus and T. ivanbureschi fringe populations differed significantly from central populations in the frequencies of individuals with non-modal vertebrae formulae. For other species no significant differences between central and fringe populations were found (Table 4). In $T$. cristatus $\times$ T. marmoratus, sixty F1 hybrids $(88.2 \%)$ have a vertebral formula with an intermediate number of thoracic vertebrae (Table 3). Six hybrids (8.8\%) possess an incomplete homeotic transformation. Among these, one has an incomplete transformation of a cervical into a thoracic vertebra. The most frequent incomplete homeotic transformation involves an asymmetrical sacrum. The frequencies of transitional sacral vertebra in hybrids and parental species are similar (G-test for independence, $\mathrm{G}=1.07, p=0.59$ ).

\section{Discussion}

Our study shows a substantial variation in the number of thoracic vertebrae in Triturus newts, suggesting the absence of strong selection against change in the number of thoracic vertebrae. In agreement with the postulations of Geoffroy St. Hilaire, Darwin and Bateson, the variation in the vertebral column is positively correlated with the number of vertebrae. Using independent contrasts we observed a statistically significant, correlated evolutionary change between an increase in the modal number of thoracic vertebrae and variation in vertebrae number. The range of variation in the number of thoracic vertebrae is also significantly higher in species with a larger modal number of thoracic vertebrae. In T. marmoratus and T. pygmaeus the variation is limited to one extra thoracic vertebra, while in crested newt species the variation range is up to four vertebrae. Although such a pattern of intraspecific variation is in agreement with Geoffroy 
281 St. Hilaire's and Darwin's rules, the observed pattern may also represent an association between

282 variation in vertebral number and differences in selection in different habitats that Triturus

283 species occupy, in particular the amount of time they spend in the terrestrial versus the aquatic

284 environment. During the terrestrial phase the limbs support the weight of the body and provide

285 forward propulsion by the synchronous use of diagonal limb pairs. In water where the body

286 weight does not need to be supported by the limbs the newts move by tail propulsion with the

287 limbs tightly held against the body to reduce hydrodynamic drag (Gvoždik \& Van Damme,

288 2006). Therefore, the selection pressures related to specific biomechanical requirements are

289 probably different with respect to the duration of the terrestrial and aquatic phase. The larger

290 variation in the number of thoracic vertebrae may indicate relaxed selection in more aquatic

291 species, but more data on different selective pressures in terrestrial versus aquatic environments

292 are needed to find out whether this is the case.

293

294 Frequencies of transitional vertebrae

295 In Triturus newts, the frequency of transitional changes at the cervico-thoracic boundary is more 296 than ten times lower than changes at the thoraco-sacral boundary. This is also observed in other 297 salamanders (Wake \& Lawson, 1973) and mammals (Galis et al., 2006). This pattern may be 298 explained by stronger interactivity and low modularity of developmental processes during the early organogenesis, or phylotypic stage, when the cervical vertebra is determined (Galis et al., 2006). At later stages, development is increasingly less interactive and more modular, such that changes are expected to be associated with fewer pleiotropic effects. The hypothesis that mutations with an effect during early organogenesis stage lead to more pleiotropic effects and as a consequence to more vulnerability and mortality than earlier or later stages was tested and strongly supported in rodents (Galis \& Metz 2001). In amphibians indirect support for this hypothesis is discussed by Galis, Wagner \& Jockusch (2003). We do not know the cause of the constraint on the number of cervical and sacral vertebra in tailed amphibians, but further studies in various amphibian groups that will consider survival rates of individuals with changes in the cervical and sacral region across ontogenetic stages should provide valuable data to solve this issue.

310 Although we hypothesized that frequencies of transitional vertebrae at the thoraco-sacral

311 boundary should be correlated to the range of variation in the number of thoracic vertebrae as in 
312 mammals (Ten Broek et al., 2012), no correlation was found. Available literature data indicate

313 that incomplete homeotic transformation of sacral vertebrae are relatively common, with up to

314 10\% across the various salamander lineages: 4.5\% in Batrachoseps attenuatus (Jockusch, 1997),

315 5.7\% in Rhyacotriton olympicus (Worthington, 1971), 6\% in Plethodon cinereus (Highton,

316 1960), up to 9\% for newt genera Lissotriton and Ichthyosaura (Arntzen et al., 2015) and between

$317 \quad 1.9 \%$ and $9.0 \%$ in Triturus newts (this study). The lower than expected incidence of transitional

318 vertebrae could result from developmental mechanisms favoring complete numbers of thoracic

319 vertebrae and/or from selection against transitional sacral vertebrae due to associated problems

320 related to an asymmetric sacrum (c.f. Galis et al., 2014). Potential problems associated to

321 asymmetrical sacrum might arise due to asymmetrical muscle attachments, blood vessels and

322 innervation, or biomechanical problems during locomotion. In salamanders, the selection

323 pressures related to specific biomechanical requirements are probably different in fully aquatic

324 larvae and metamorphosed individuals that spend most of their time on land. Furthermore,

325 selection pressures may vary with respect to the duration of annual aquatic and terrestrial phase.

326 More detailed morphological and functional studies of locomotion of larval and metamorphic

327 stages could shed more light on the functional significance of variation in the axial skeleton in

328 Triturus newts. However, it is possible that our results are biased as we have not included the full

329 range of transitional vertebrae. We scored only easily identifiable transitional vertebrae with

330 complete morphological transformations of one side of the vertebra under the assumption that

331 the frequency of these transitional vertebrae reflects the total amount of homeotic

332 transformations. Nonetheless, initial mutations for homeotic transformations can lead to a whole

333 series of gradually transitional homeotic transformations; in the case of thoraco-sacral vertebrae

334 ranging from predominantly thoracic and only slightly sacral to predominantly sacral and slightly

335 thoracic. Inclusion of all transitional vertebral morphologies might change the observed

336 relationship between incomplete homeotic transformations and changes in the number of

337 thoracic vertebrae in newts.

338

339

Hybridization, marginality and homeotic transformations

340 Hybridization and marginality significantly increase variability in the number of thoracic

341 vertebrae but there is no change in the frequency of transitional vertebrae. Crosses between $T$.

342 cristatus (15 vertebrae, range 13-16) and T. marmoratus (12 vertebrae, range 12-13) produced 
343 phenotypes with 13 thoracic vertebrae, an intermediate number. It is interesting to note that 13

344 thoracic vertebrae is the only number that is shared by both parental species. In T. cristatus $\times T$.

345 marmoratus offspring there is considerable mortality and almost all of F1 hybrids ( $\sim 90 \%)$ had $T$.

346 cristatus as mother. The marmoratus-mothered specimens were all male, due to low survival of

347 female embryos (Arntzen et al., 2009). Developmental anomalies in T. cristatus $\times$ T. marmoratus

348 crosses, including more digital anomalies compared with parental species (hybrids 16.9\%,

349 parental species pooled 5.4\%) (Vallée, 1959; more data in Arntzen \& Wallis, 1991) are observed,

350 and therefore, the higher number of changes in the axial skeleton may be related to a generally

351 higher number of anomalies. The high mortality may also influence the incidence of the

352 variability and transitional vertebrae.

353 Significantly higher frequency of changes in vertebral formula in fringe populations of $T$.

354 ivanbureschi and T. dobrogicus species may well have to do with the confirmed presence of

355 hybridization in the contact zones of T. cristatus and T. dobrogicus populations (Mikulíček et al., 356 2012), of T. carnifex and T. dobrogicus populations (Wallis \& Arntzen, 1989) and of T.

357 ivanbureschi and T. macedonicus populations (Arntzen, Wielstra \& Wallis, 2014). However, the

358 effect of the various genotype combinations on the survival rate and morphology of these species

359 remains to be studied.

360 In conclusion, Triturus newts have a relatively large amount of variation in the number of

361 thoracic vertebrae, both with respect to the frequency of non-modal numbers and the range of

362 variation. In agreement with Geoffroy St. Hilaire's rule, variation was larger in species with a

363 larger number of thoracic vertebrae. The absence of a correlation between the frequency of

364 homeotic change (transitional sacral vertebrae, $\left.S_{\text {tr }}\right)$ and variation in the number of vertebrae $\left(T_{\text {var }}\right.$,

$365 \mathrm{~T}_{\text {range }}$ ) could be a result of developmental mechanisms that favour complete numbers of presacral

366 vertebrae and/or selection against transitional vertebrae in this group of tailed amphibians.

367

368 Acknowledgements

369

370 We thank Hans Metz and Joost Woltering for discussions, Ben Wielstra for providing a

371 distribution map and Marieke Vinkenoog for help with $\mathrm{X}$ - ray imaging.

372

373 References 
374

375

376

377

378

379

380

381

382

383

384

385

386

387

388

389

390

391

392

393

394

395

396

397

398

399

400

401

402

403

Adolphi H. 1898. Über das Wandern der Extremitätenplexus und des Sacrum bei Triton taeniatus. Morphologisches Jahrbuch 25: 544-554

Ahlberg PE, Clack JA, Blom H. 2005. The axial skeleton of the Devonian tetrapod Ichthyostega. Nature 437: 137-140 DOI:10.1038/nature.03893

Arntzen JW, Wallis GP. 1991. Restricted gene flow in a moving hybrid zone of the newts Triturus cristatus and T. marmoratus in western France. Evolution 45 (4): 805-826

Arntzen JW. 2003. Triturus cristatus Superspezies - Kammolch-Artenkreis. (Triturus cristatus (Laurenti, 1768) - Noërdlicher Kammolch, Triturus carnifex (Laurenti, 1768) Italienischer Kammolch. Triturus dobrogicus (Kiritzescu, 1903) - DonauKammolch,Triturus karelinii (Strauch, 1870) - Suëdlicher Kammolch). In: K. Grossenbacher, B. Thiesmeier, eds. Handbuch der Reptilien und Amphibien Europas, Band 4/IIA: Schwanzlurche (Urodela) IIA. Wiebelsheim: Aula-Verlag, 421-514

Arntzen JW, Jehle R, Bardakci F, Burke T, Wallis GP. 2009. Asymmetric viability of reciprocal-cross hybrids between crested and marbled newts (Triturus cristatus and $T$. marmoratus). Evolution 63 (5): 1191-202 DOI: 10.1111/j.1558-5646.2009.00611.x

Arntzen JW, Wielstra B, Wallis GP. 2014. The modality of nine Triturus newt hybrid zones assessed with nuclear, mitochondrial and morphological data. Biological Journal of the Linnean Society 113 (2): 604-622 DOI: 10.1111/bij.12358

Arntzen JW, Beukema W, Galis F, Ivanović A. 2015. Vertebral number is highly evolvable in salamanders and newts (family Salamandridae) and variably associated with climatic parameters. Contributions to Zoology 84 (2): 87-116

Aulehla A, Pourquié O. 2010. Signaling gradients during paraxial mesoderm development. Cold Spring Harbor Perspectives in Biology 2 (2): a000869 DOI:10.1101/cshperspect.a000869

Bateson W. 1894. Materials for the Study of Variation. London: MacMillan

Carapuço M, Nóvoa A, Bobola N, Mallo M. 2005. Hox genes specify vertebral types in the presomitic mesoderm. Genes \& Development 19 (18): 2116-2121

Carroll RL. 1997. Patterns and Processes of Vertebrate Evolution. Cambridge: Cambridge University Press 
404

405

406

407

408

409

410

411

412

413

414

415

416

417

418

419

420

421

422

423

424

425

426

427

428

429

430

431

432

433

Cooke J, Zeeman ECA. 1976. Clock and wavefront model for control of the number of repeated structures during animal morphogenesis. Journal of Theoretical Biology 58 (2): 455-476

Crnobrnja J, Džukić G, Krstić N, Kalezić ML. 1997. Evolutionary and paleogeographic effects on the distribution of the Triturus cristatus superspecies in the central Balkans. Amphibia-Reptilia 18 (4): 321-332 DOI: 10.1163/156853897X00378

Darwin CR. 1860. The Origin of Species. New York: D. Appleton and Company

Dequéant ML, Pourquié O. 2008. Segmental patterning of the vertebrate embryonic axis. Nature Review Genetics 9: 370-382 DOI: 10.1038/nrg2320

Diezdel-Corral R, Olivera-Martinez I, Goriely A, Gale E, Maden M, Storey K. 2003. Opposing FGF and retinoid pathways control ventral neural pattern, neuronal differentiation, and segmentation during body axis extension. Neuron 40 (1): 65-79

Dingerkus G, Uhler LD. 1977. Enzyme clearing of alcian blue stained whole small vertebrates for demonstration of cartilage. Stain Technology 52 (4): 229-232

Dubrulle J, McGrew MJ, Pourquié O. 2001. FGF signaling controls somite boundary position and regulates segmentation clock control of spatiotemporal Hox gene activation. Cell $\mathbf{1 0 6}$ (2):219-32

Felsenstein J. 1985. Phylogenies and the comparative method. American Naturalist 125 (1): 115

Galis F, Metz JAJ. 2001. Testing the vulnerability of the phylotypic stage: on modularity and evolutionary conservation. Journal of Experimental Zoology Part B: Molecular and Developmental Evolution 291 (2): 195-204

Galis F, Metz JAJ. 2003. Anti-cancer selection as a source of developmental and evolutionary constraints. Bioessays 25 (11): 1035-1039

Galis F, Wagner GP, Jockusch E. 2003. Why is limb regeneration possible in amphibians but not in reptiles, birds and mammals? Evolution \& Development 5 (2): 208-220

Galis F, Van Dooren TJ, Feuth JD, Metz JA,Witkam A, Ruinard S, Steigenga MJ, Wijnaendts LC. 2006. Extreme selection in humans against homeotic transformations of cervical vertebrae. Evolution 60 (12): 2643-2654

Galis F, Carrier DR, Alphen J, Van der Mije SD, Doorn TV, Metz JAJ, Ten Broek CMA. 2014. Fast running restricts evolutionary change of the vertebral column in mammals. . 
434

435

436

437

438

439

440

441

442

443

444

445

446

447

448

449

450

451

452

453

454

455

456

457

458

459

460

461

462

463

464

Proceedings of the National Academy of Sciences of the United States of America 111 (31): 11401-11406 DOI: 10.1073/pnas.1401392111

Geoffroy SHI. 1832. Histoire Générale et Particulière des Anomalies de L'organisation chez L'homme et les Animaux. Paris: J.-B. Baillère, Libraire de l' Academie Royale de Médecine

Gerecht A. 1929. Über die Richtung der phyletischenWanderung der Sakralregionbei Triton cristatus und Triton taeniatus. Bulletin de la Société de biologie de Lettonie 1(1): 9-19

Gomez C, Özbudak EM, Wunderlich J, Baumann D, Lewis J, Pourquié 2008. Control of segment number in vertebrate embryos. Nature 454 (7202): 335-339

Gomez C, Pourquié O. 2009. Developmental control of segment numbers in vertebrates. Journal of Experimental Zoology Part B: Molecular and Developmental Evolution. 312 (6): 533-544 DOI: 10.1002/jez.b.21305

Gvoždik L,Van Damme R. 2006. Triturus newts defy the running-swimming dilemma. Evolution 60 (10): 2110-2121

Harima Y, Takashima Y, Ueda Y, Ostsuka T, Kageyama R. 2013. Accelerating the tempo of the segmentation clock by reducing the number of introns in the $\underline{H e s} 7$ Gene. Cell Reports 3 (1): 1-7 DOI: 10.1016/j.celrep.2012.11.012

Highton R. 1960. Heritability of geographic variation in trunk segmentation in the red- backed salamander, Plethodon cinereus. Evolution 14 (3): 351-360

Jockusch EL. 1997. Geographic variation and phenotypic plasticity of number of trunk vertebrae in slender salamanders, Batrachoseps (Caudata: Plethodontidae). Evolution 51 (6): 1966-1982 DOI:10.2307/2411017

Lescure J, de Massary J-C. 2012. Atlas des Amphibiens et Reptiles de France. Paris: Muséum national d'Histoire naturelle

Litvinchuk SN, Borkin LJ. 2003. Variation in number of trunk vertebrae and in count of costal grooves in salamanders of the family Hynobiidae. Contributions to Zoology 72 (4):195209

Mallo M, Wellik D, Deschamps J. 2010. Hox genes and regional patterning of the vertebrate body plan. Developmental Biology 344 (1): 7-15 DOI: 10.1016/j.ydbio.2010.04.024

Mikulíček P, Horák A, Zavadil V, Kautman J, Piálek J. 2012. Hybridization between three crested newt species (Triturus cristatus superspecies) in the Czech Republic and 
465

466

467

468

469

470

471

472

473

474

475

476

477

478

479

480

481

482

483

484

485

486

487

488

489

490

491

492

493

494

495

Slovakia: comparison of nuclear markers and mitochondrial DNA. Folia Zoologica 61 (3-4): 202-218

Müller J, Scheyer TM, Head JJ, Barrett PM, Werneburg I, Ericson PGP, Pol D, SanchezVillagra MR. 2010. Homeotic effects, somitogenesis and the evolution of vertebral numbers in recent and fossil amniotes. Proceedings of the National Academy of Sciences of the United States of America 107 (5): 2118-2123

Palmeirim I, Henrique D, Ish-Horowicz D, Pourquié O. 1997. Avian hairy gene expression identifies a molecular clock linked to vertebrate segmentation and somitogenesis. Cell 91 (5): $639-48$

Peabody RB, Brodie ED. 1975. Effect of temperature, salinity and photoperiod on the number of trunk vertebrae in Ambystoma maculatum. Copeia 1975 (4): 741-746

Schroeter C, Oates AC. 2010. Segment number and axial identity in a segmentaion clock period mutant. Current Biology 20 (14): 1254-1258

Starck D. 1979. Vergleichende Anatomie der Wirbeltiere. Berlin: Springer Verlag

Ten Broek CM, Bakker AJ,Varela-Lasheras I, Bugiani M, Van Dongen S, Galis F. 2012. Evo-Devo of the human vertebral column: on homeotic transformations, pathologies and prenatal selection. Evolutionary Biology 39(4): 456-471

Vallée L. 1959. Recherches sur Triturus blasii de l'Isle, hybride naturel de Triturus cristatus Laur. x Triturus marmoratus Latr. Mém. Bulletin de la Société zoologique de France 31: $1-95$

Varela-Lasheras I, Bakker A, Mije S, Metz J, Alphen J, Galis F. 2011. Breaking evolutionary and pleiotropic constraints in mammals: On sloths, manatees and homeotic mutations. EvoDevo 2: 11 DOI:10.1186/2041-9139-2-11

Wallis GP, Arntzen JW. 1989. Mitochondrial-DNA variation in the crested newt superspecies: limited cytoplasmic gene flow among species. Evolution 43 (1): 88-10 DOI: $10.2307 / 2409166$

Wake DB, Lawson R. 1973. Developmental and adult morphology of the vertebral column in the plethodontid salamander Eurycea bislineata, with comments on vertebral evolution in the amphibian. Journal of Morphology 139 (3):251-299 DOI: 10.1002/jmor.1051390302

Woltering JM. 2012. From lizard to snake; behind the evolution of an extreme body plan. Current Genomics 13 (4): 289-299 DOI:10.2174/138920212800793302 
496

497

498

499

500

501

502

503

504

\section{Wong SFL, Agarwal W, Mansvield JH, Denans N, Schwartz MG, Prosser HM, Pourquié}

O. 2015. Independent regulation of vertebral number and vertebral identity by microRNA-196 paralogs. Proceedings of the National Academy of Sciences of the United States of America 112 (35): E4884-93 DOI: 10.1073/pnas1512655112

Woolfenden GE. 1961. Postcranial osteology of the waterfowl. Bulletin of the Florida State Museum 6: (1) -129

Worthington RD. 1971. Postmetamorphic changes in the vertebrae of the marbled salamander Ambystoma opacum Gravenhorst (Amphibia, Caudata). El Paso: Texas Western Press 
505 Figure 1.

506 The regionalization of the vertebral column in Triturus newts and schematic presentation of

507 scored homeotic transformations (example of T. marmoratus). A) vertebral column without

508 homeotic transformation and regular number of vertebrae - the first three caudal vertebrae are

509 shown; B) incomplete homeotic transformations of cervical vertebra into thoracic; C) complete

510 homeotic transformation of cervical into thoracic vertebra; D) transitional sacral vertebra with

511 thoracic rib at one side and sacral rib at the other side followed by transitional vertebra with

512 sacral rib at the one side and no rib at the other; E) transitional thoraco-sacral vertebra, with

513 thoracic rib at one side and sacral rib at the other, followed by regular sacral vertebra.

cervical vertebra thoracic vertebra sacral vertebra caudo-sacral vertebra caudal vertebra $>$ thoracic rib sacral rib

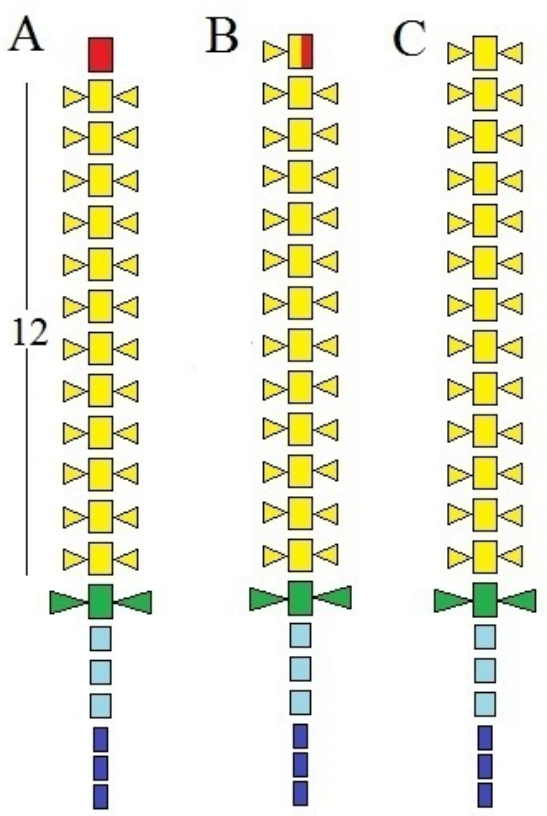

D

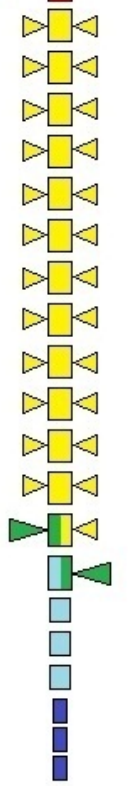

E

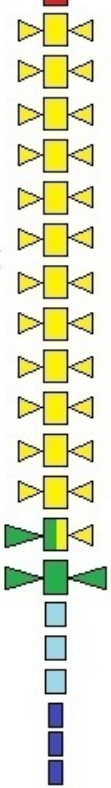


515 Figure 2.

516 Calibrated phylogeny for the genus Triturus with the modal number of vertebrae indicated by

517 colour code (after Arntzen et al., 2015).

518

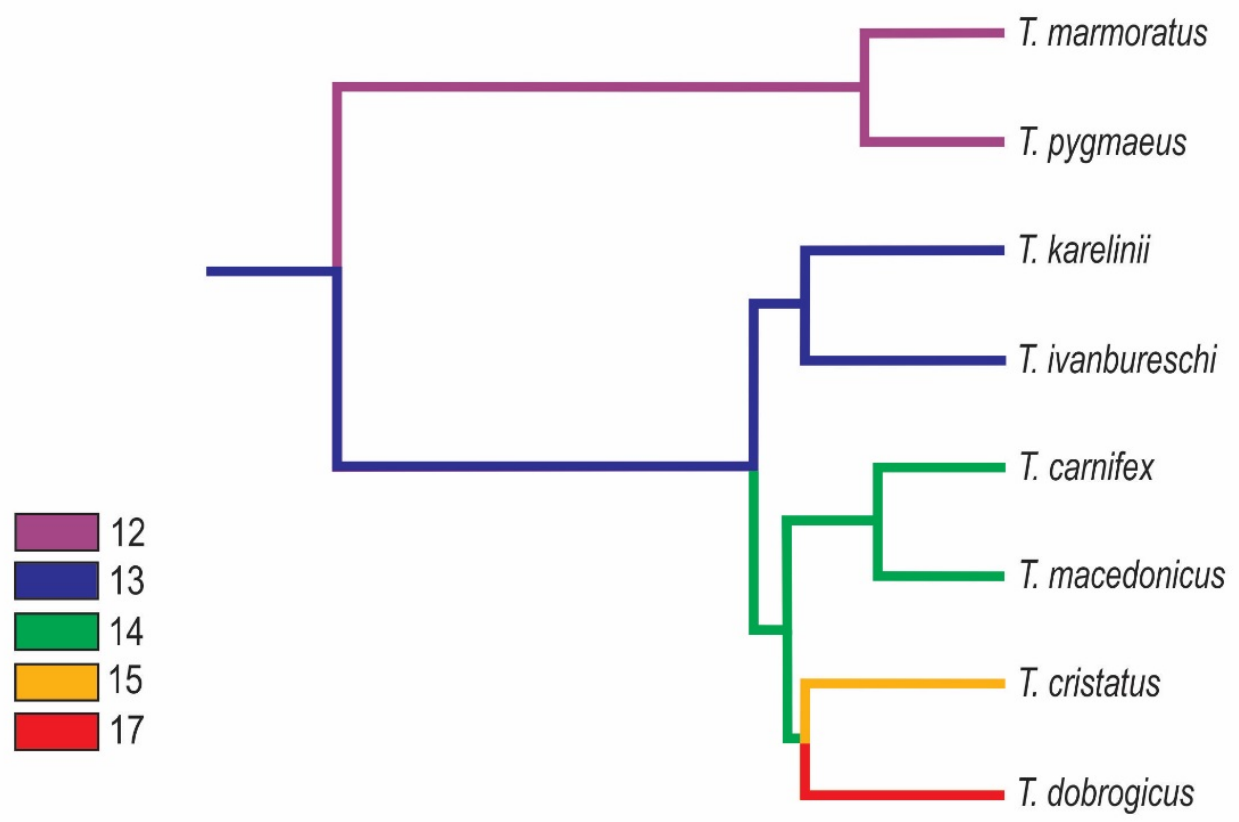

Ma $\begin{array}{lllllllll} & 35 & 30 & 25 & 20 & 15 & 10 & 5 & 0\end{array}$


520 Figure 3.

521 Distribution of eight Triturus species across Europe and adjacent Asia. Studied populations are

522 marked by solid dots (central populations) and open dots (fringe populations). For detailed 523 information see Supplementary Table S1.

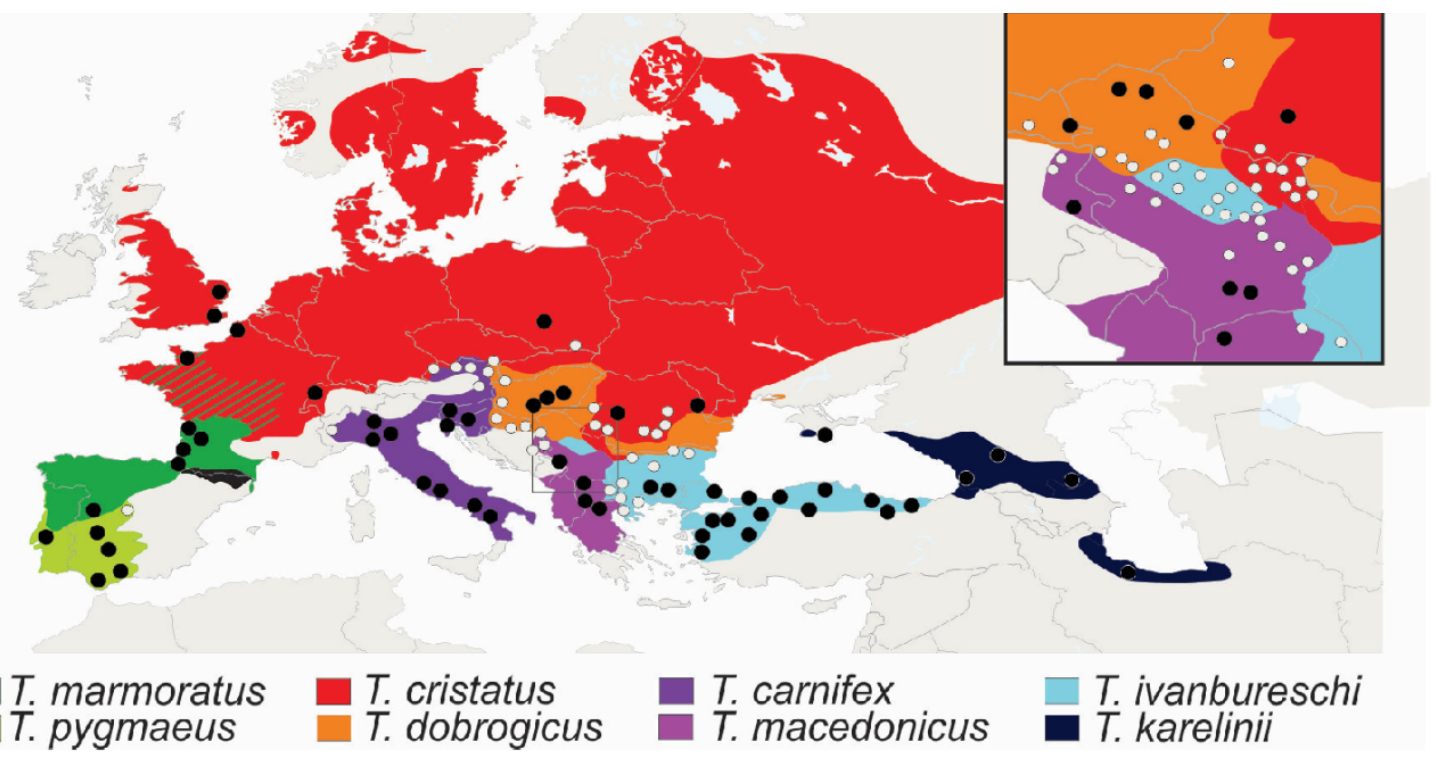




\section{Figure 4.}

527 Homeotic transformations recorded: A) complete vertebral column without homeotic

528 transformations and transitional vertebrae. B) transitional cervical vertebra (cervical into

529 thoracic) (1); C) complete homeotic transformation of cervical into thoracic vertebra (2) and

530 transitional sacral vertebra with thoracic rib on the right side and sacral rib on the other side

531 followed by sacral vertebra (3); D) Transitional sacral vertebra - first vertebra with thoracic rib

532 on the right side and sacral rib on the left side, followed by second transitional vertebra, with

533 sacral rib on the right side and no rib attached on the left side (transitional sacral vertebra with a

534 left side asymmetry) (4); Transformations are marked by arrows and showed in close-up at the

535 bottom of the Figure.
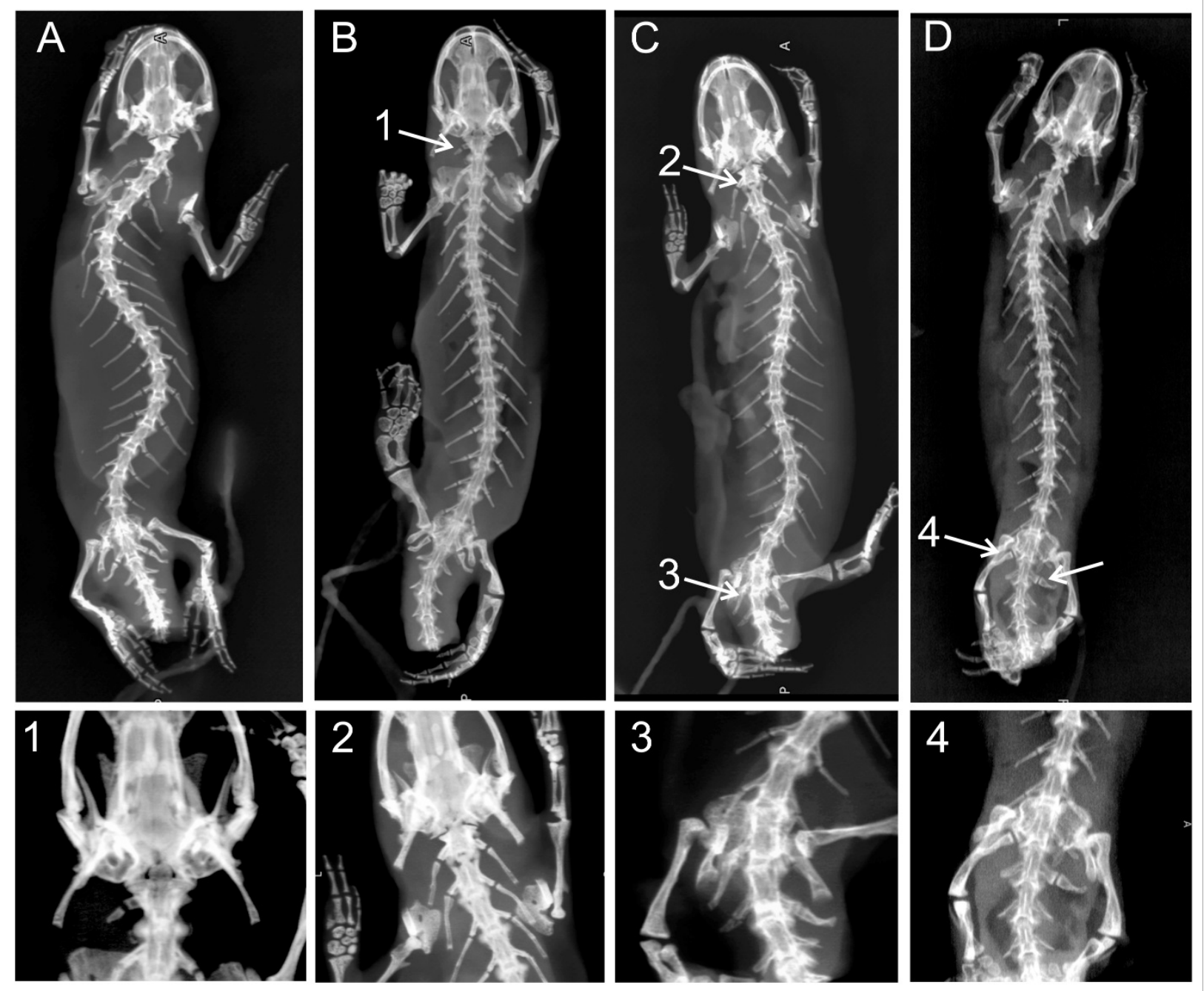
538 Table 1.

539 The number of thoracic vertebrae in Triturus species (central populations only). Modal numbers

540 of thoracic vertebrae in vertebral formulae are shown in bold. $\mathrm{S}_{\mathrm{tr}}$ - percentage of individuals with

541 transitional vertebrae at thoraco-sacral boundary. $\mathrm{T}_{\mathrm{var}}-$ percentage of individuals with the

542 complete number of thoracic vertebrae different from the modal number.

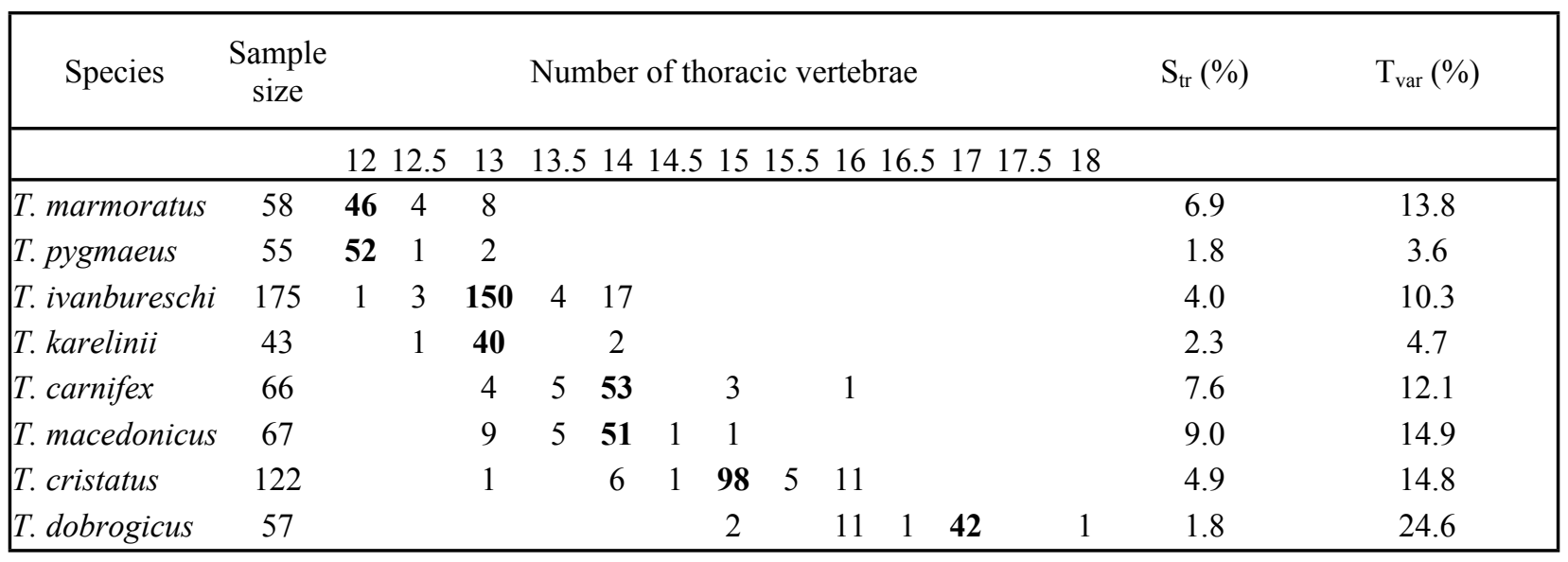


545 Table 2.

546 Overview of homeotic transformations observed in Triturus species. Number and percentage of

547 individuals with transitional vertebrae are given. Left and right asymmetries of transitional sacral

548 vertebra are shown separately.

\begin{tabular}{|c|c|c|c|c|c|c|c|c|c|c|c|}
\hline \multirow[b]{2}{*}{ Species } & \multirow[b]{2}{*}{$\begin{array}{c}\text { Sample } \\
\text { size }\end{array}$} & \multicolumn{5}{|c|}{ Cervical to thoracic } & \multicolumn{2}{|c|}{ Transitional sacral } & \multicolumn{3}{|c|}{ Thoracic to sacral } \\
\hline & & Transitional & $\%$ & Complete & Incomplete & $\%$ & Left & Right & $\%$ & Incomplete & $\%$ \\
\hline T. marmoratus & 58 & 5 & 8.6 & 0 & 1 & 1.7 & 1 & 3 & 6.9 & 0 & \\
\hline T. pygmaeus & 55 & 1 & 1.8 & 0 & 0 & & 1 & 0 & 1.8 & 0 & \\
\hline T. ivanbureschi & 361 & 25 & 6.9 & 1 & 3 & 1.1 & 6 & 12 & 5.0 & 3 & 0.8 \\
\hline T. karelinii & 43 & 1 & 2.3 & 0 & 0 & & 0 & 1 & 2.3 & 0 & \\
\hline T. carnifex & 123 & 8 & 6.5 & 0 & 0 & & 6 & 2 & 6.5 & 0 & \\
\hline T. macedonicus & 226 & 14 & 6.2 & 0 & 1 & 0.4 & 8 & 4 & 5.3 & 1 & 0.4 \\
\hline T. cristatus & 286 & 16 & 5.6 & 2 & 1 & 1.0 & 10 & 3 & 4.5 & 0 & \\
\hline T. dobrogicus & 216 & 13 & 6.0 & 0 & 0 & & 7 & 6 & 6.0 & 0 & \\
\hline Total & 1368 & 83 & 6.1 & 3 & 6 & 0.6 & 39 & 31 & & 4 & 0.3 \\
\hline
\end{tabular}

549 


\section{Table 3.}

552 The number of thoracic vertebrae in T. cristatus $\times$ T. marmoratus $\mathrm{F}_{1}$ hybrids and parental 553 species. Modal numbers of thoracic vertebrae in vertebral formulae are shown in bold. $\mathrm{S}_{\mathrm{tr}}-$ 554 percentage of individuals with transitional vertebrae at thoraco-sacral boundary. $\mathrm{T}_{\mathrm{var}}-$ percentage 555 of individuals with the complete number of thoracic vertebrae different from the modal number.

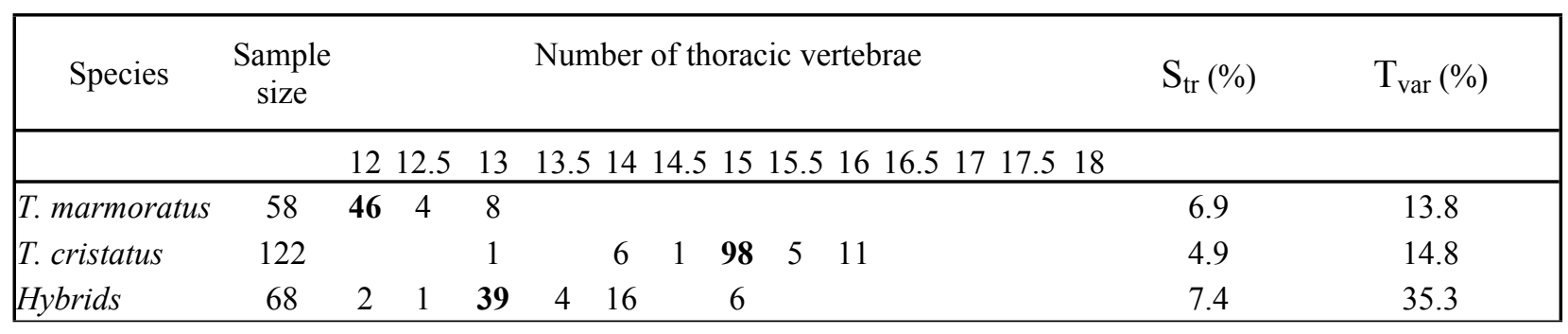

556

557 
558 Table 4.

559 The number of individuals with regular and changed vertebral formulae in "central" and

560 "fringe" populations.

\begin{tabular}{|c|c|c|c|c|c|c|}
\hline \multirow[b]{2}{*}{ Species } & \multicolumn{2}{|c|}{$\begin{array}{c}\text { Number with modal vertebral } \\
\text { formula }\end{array}$} & \multicolumn{2}{|c|}{$\begin{array}{c}\text { Number with non-modal } \\
\text { vertebral formula }\end{array}$} & \multirow[b]{2}{*}{ G } & \multirow[b]{2}{*}{$p$} \\
\hline & Central & Fringe & Central & Fringe & & \\
\hline T. ivanbureschi & 150 & 110 & 25 & 76 & 18.86 & $* * *$ \\
\hline T. carnifex & 53 & 37 & 13 & 20 & 2.09 & $\mathrm{~ns}$ \\
\hline T. macedonicus & 51 & 122 & 16 & 37 & 0.006 & $\mathrm{~ns}$ \\
\hline T. cristatus & 98 & 130 & 24 & 34 & 0.032 & ns \\
\hline T. dobrogicus & 42 & 67 & 15 & 92 & 6.65 & $* *$ \\
\hline Total & 394 & 466 & 83 & 259 & & \\
\hline
\end{tabular}

561

562 


\section{Figure 1 (on next page)}

Schematic presentation of the vertebral column in Triturus newts and homeotic transformations scored

Figure 1. The regionalization of the vertebral column in Triturus newts and schematic presentation of scored homeotic transformations (example of T. marmoratus). A) vertebral column without homeotic transformation and regular number of vertebrae - the first three caudal vertebrae are shown; B) incomplete homeotic transformations of cervical vertebra into thoracic; C) complete homeotic transformation of cervical into thoracic vertebra; D) transitional sacral vertebra with thoracic rib at one side and sacral rib at the other side followed by transitional vertebra with sacral rib at the one side and no rib at the other; E) transitional thoraco-sacral vertebra, with thoracic rib at one side and sacral rib at the other, followed by regular sacral vertebra. 


\begin{tabular}{llllll}
\hline cervical vertebra \\
thoracic vertebra \\
sacral vertebra \\
caudo-sacral vertebra \\
caudal vertebra \\
thoracic rib \\
sacral rib
\end{tabular}


Figure 2 (on next page)

Calibrated phylogeny for the genus Triturus with the modal number of vertebrae indicated by colour code

Figure 2. Calibrated phylogeny for the genus Triturus with the modal number of vertebrae indicated by colour code (after Arntzen et al., 2015). 


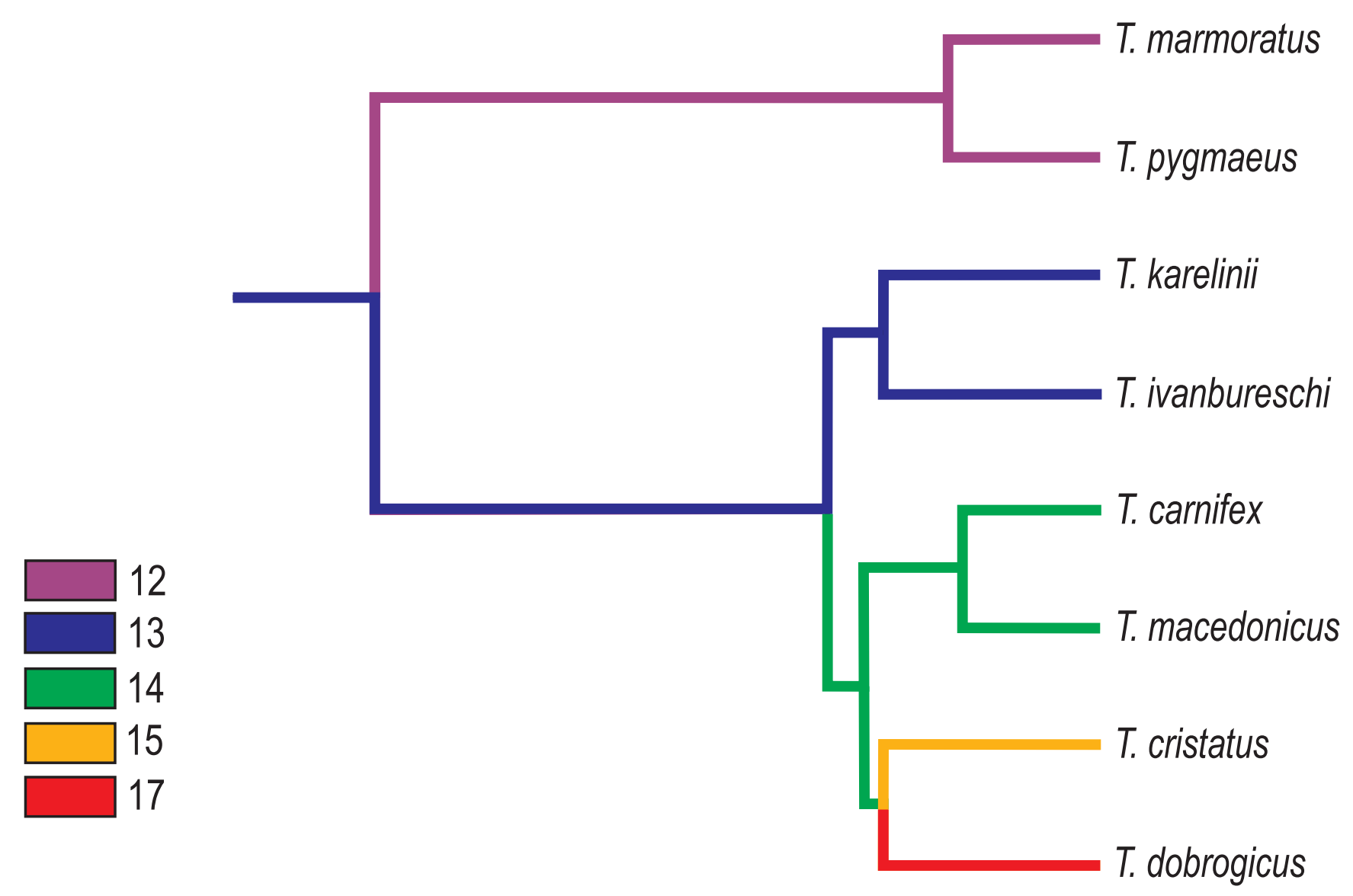

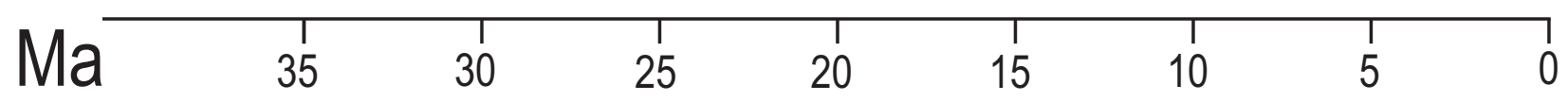




\section{Figure 3 (on next page)}

Distribution of Triturus species and geographic positions of populations

Figure 3. Distribution of eight Triturus species across Europe and adjacent Asia. Studied populations are marked by solid dots (central populations) and open dots (fringe populations). For detailed information see Supplementary Table S1. 


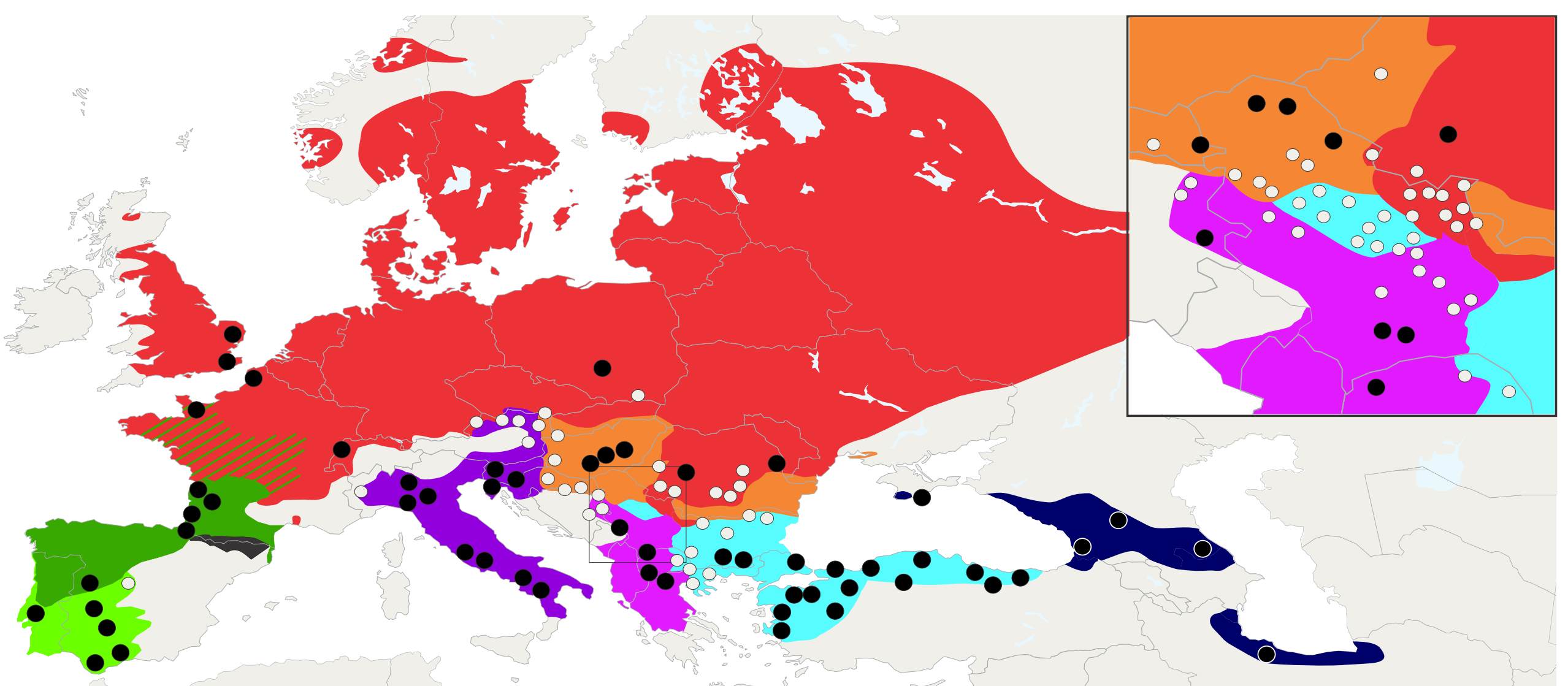

T. marmoratus

T. pygmaeus

T. cristatus

T. dobrogicus
- T. carnifex

- T. macedonicus $\square$ T. ivanbureschi

- T. karelinii 


\section{4}

X-ray images of homeotic transformations recorded

Figure 4. Homeotic transformations recorded: A) complete vertebral column without homeotic transformations and transitional vertebrae. B) transitional cervical vertebra (cervical into thoracic) (1); C) complete homeotic transformation of cervical into thoracic vertebra (2) and transitional sacral vertebra with thoracic rib on the right side and sacral rib on the other side followed by sacral vertebra (3); D) Transitional sacral vertebra - first vertebra with thoracic rib on the right side and sacral rib on the left side, followed by second transitional vertebra, with sacral rib on the right side and no rib attached on the left side (transitional sacral vertebra with a left side asymmetry) (4); Transformations are marked by arrows and showed in close-up at the bottom of the Figure. 

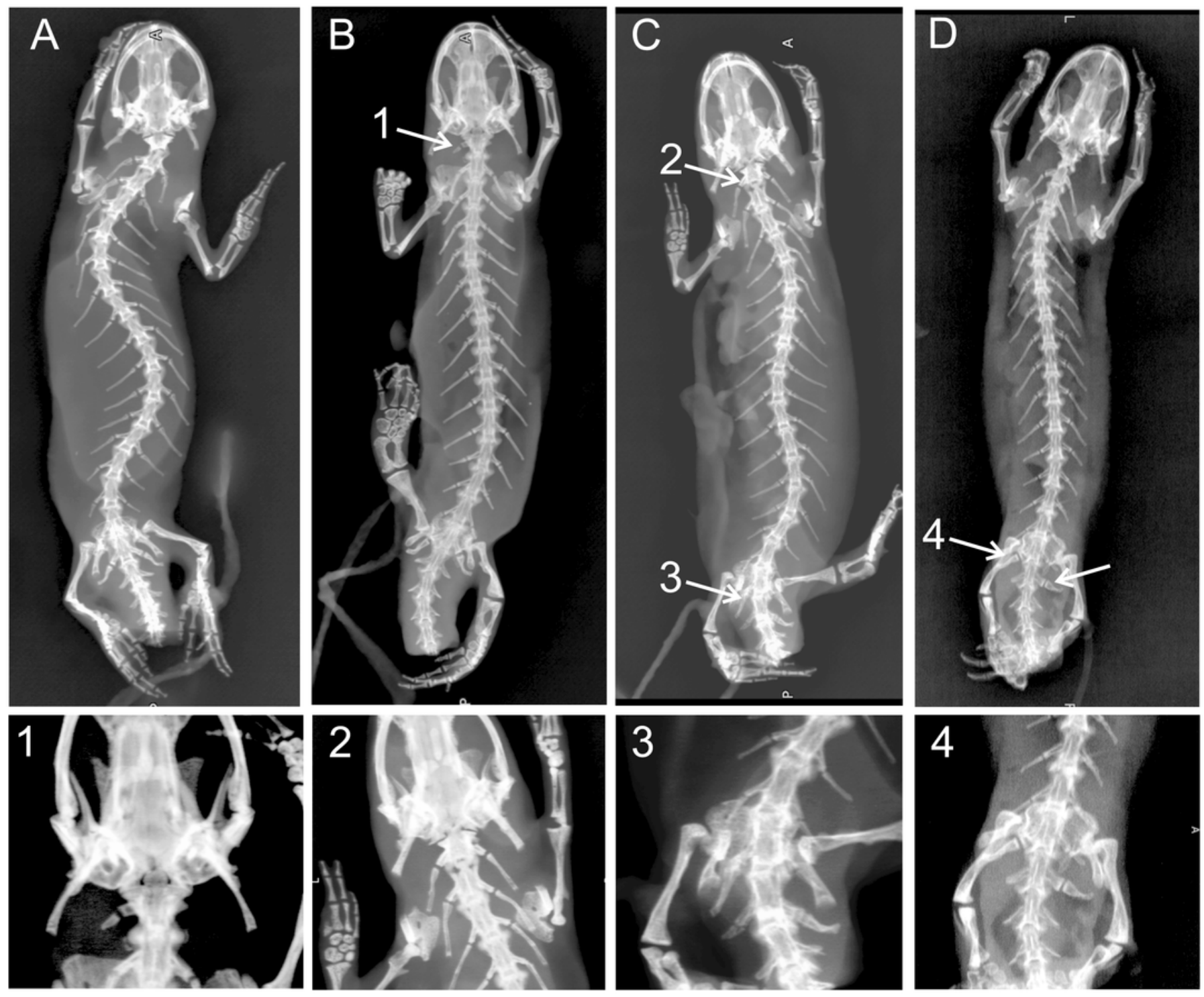


\section{Table $\mathbf{1}$ (on next page)}

The number of thoracic vertebrae in Triturus species

Table 1. The number of thoracic vertebrae in Triturus species (central populations only). Modal numbers of thoracic vertebrae in vertebral formulae are shown in bold. $\mathrm{S}_{\mathrm{tr}}-$ percentage of individuals with transitional vertebrae at thoraco-sacral boundary. $T_{\text {var }}$ percentage of individuals with the complete number of thoracic vertebrae different from the modal number. 


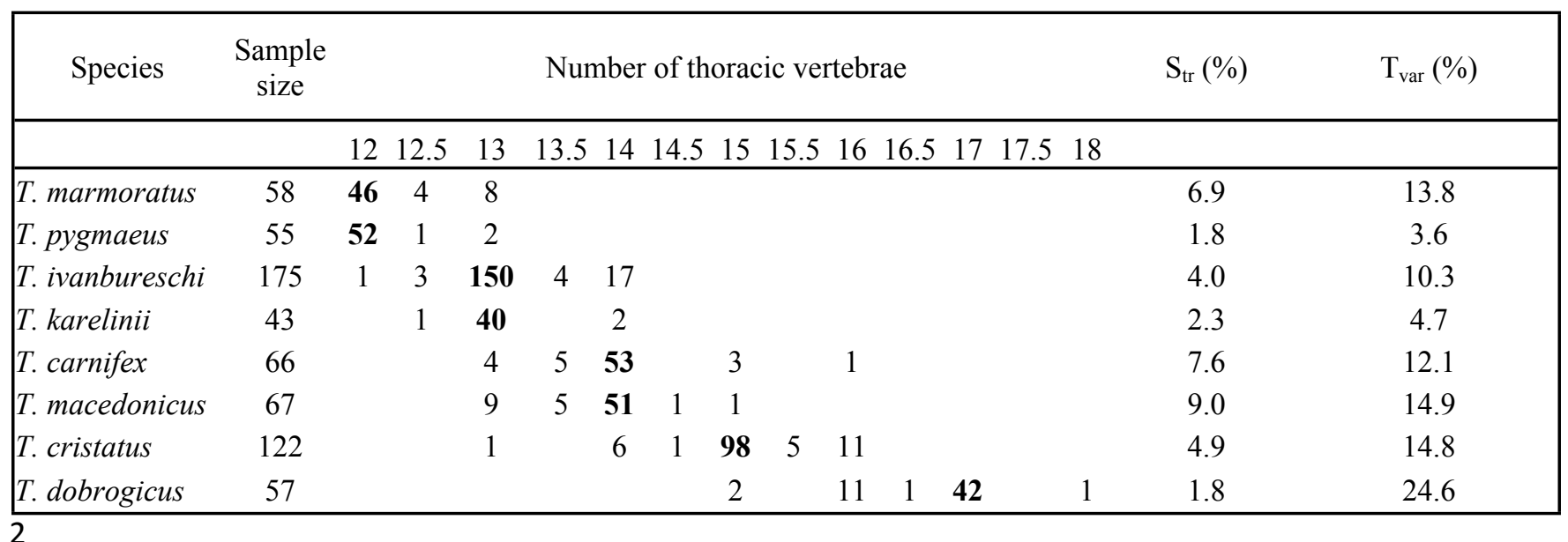




\section{Table 2 (on next page)}

Homeotic transformations observed in Triturus

Table 2. Overview of homeotic transformations observed in Triturus species. Number and percentage of individuals with transitional vertebrae are given. Left and right asymmetries of transitional sacral vertebra are shown separately. 


\begin{tabular}{|c|c|c|c|c|c|c|c|c|c|c|c|}
\hline & & & \multicolumn{4}{|c|}{ Cervical to thoracic } & \multicolumn{2}{|c|}{ Transitional sacral } & \multicolumn{3}{|c|}{ Thoracic to sacral } \\
\hline Species & $\begin{array}{c}\text { Sample } \\
\text { size }\end{array}$ & Transitional & $\%$ & Complete & Incomplete & $\%$ & Left & Right & $\%$ & Incomplete & $\%$ \\
\hline T. marmoratus & 58 & 5 & 8.6 & 0 & 1 & 1.7 & 1 & 3 & 6.9 & 0 & \\
\hline T. pygmaeus & 55 & 1 & 1.8 & 0 & 0 & & 1 & 0 & 1.8 & 0 & \\
\hline T. ivanbureschi & 361 & 25 & 6.9 & 1 & 3 & 1.1 & 6 & 12 & 5.0 & 3 & 0.8 \\
\hline T. karelinii & 43 & 1 & 2.3 & 0 & 0 & & 0 & 1 & 2.3 & 0 & \\
\hline T. carnifex & 123 & 8 & 6.5 & 0 & 0 & & 6 & 2 & 6.5 & 0 & \\
\hline T. macedonicus & 226 & 14 & 6.2 & 0 & 1 & 0.4 & 8 & 4 & 5.3 & 1 & 0.4 \\
\hline T. cristatus & 286 & 16 & 5.6 & 2 & 1 & 1.0 & 10 & 3 & 4.5 & 0 & \\
\hline T. dobrogicus & 216 & 13 & 6.0 & 0 & 0 & & 7 & 6 & 6.0 & 0 & \\
\hline Total & 1368 & 83 & 6.1 & 3 & 6 & 0.6 & 39 & 31 & & 4 & 0.3 \\
\hline
\end{tabular}

2 


\section{Table 3 (on next page)}

The number of thoracic vertebrae in $T$. cristatus $\times T$. marmoratus hybrids

Table 3. The number of thoracic vertebrae in $T$. cristatus $\times T$. marmoratus $F_{1}$ hybrids and parental species. Modal numbers of thoracic vertebrae in vertebral formulae are shown in bold. $S_{\mathrm{tr}}$ - percentage of individuals with transitional vertebrae at thoraco-sacral boundary. $T_{\text {var }}$ percentage of individuals with the complete number of thoracic vertebrae different from the modal number. 


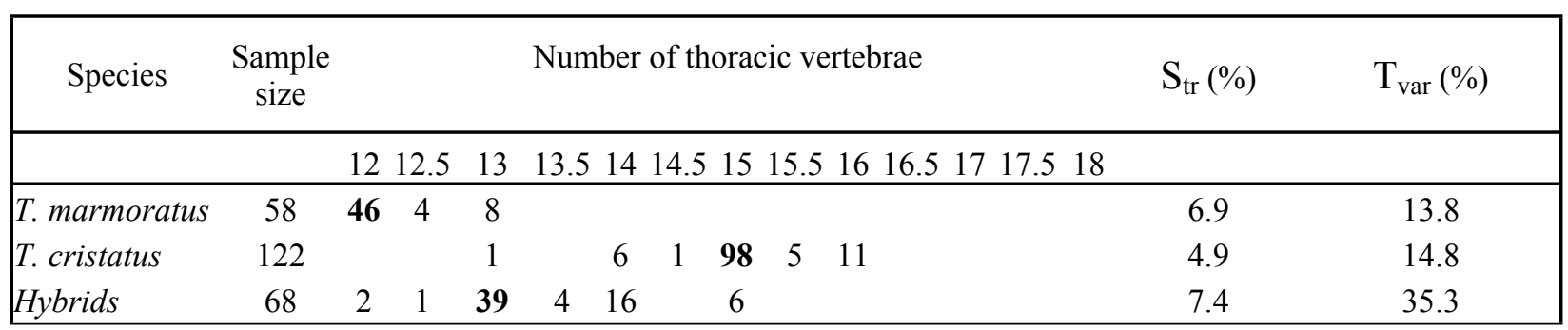

2 


\section{Table 4 (on next page)}

The number of individuals with regular and changed vertebral formulae in central and fringe populations of species with parapatric distributions

Table 4. The number of individuals with regular and changed vertebral formulae in "central" and "fringe" populations. 


\begin{tabular}{|c|c|c|c|c|c|c|}
\hline \multirow[b]{2}{*}{ Species } & \multicolumn{2}{|c|}{$\begin{array}{l}\text { Number with modal vertebral } \\
\text { formula }\end{array}$} & \multicolumn{2}{|c|}{$\begin{array}{c}\text { Number with non-modal } \\
\text { vertebral formula }\end{array}$} & \multirow[b]{2}{*}{ G } & \multirow[b]{2}{*}{$p$} \\
\hline & Central & Fringe & Central & Fringe & & \\
\hline T. ivanbureschi & 150 & 110 & 25 & 76 & 18.86 & $* * *$ \\
\hline T. carnifex & 53 & 37 & 13 & 20 & 2.09 & ns \\
\hline T. macedonicus & 51 & 122 & 16 & 37 & 0.006 & ns \\
\hline T. cristatus & 98 & 130 & 24 & 34 & 0.032 & ns \\
\hline T. dobrogicus & 42 & 67 & 15 & 92 & 6.65 & $* *$ \\
\hline Total & 394 & 466 & 83 & 259 & & \\
\hline
\end{tabular}

2

3 